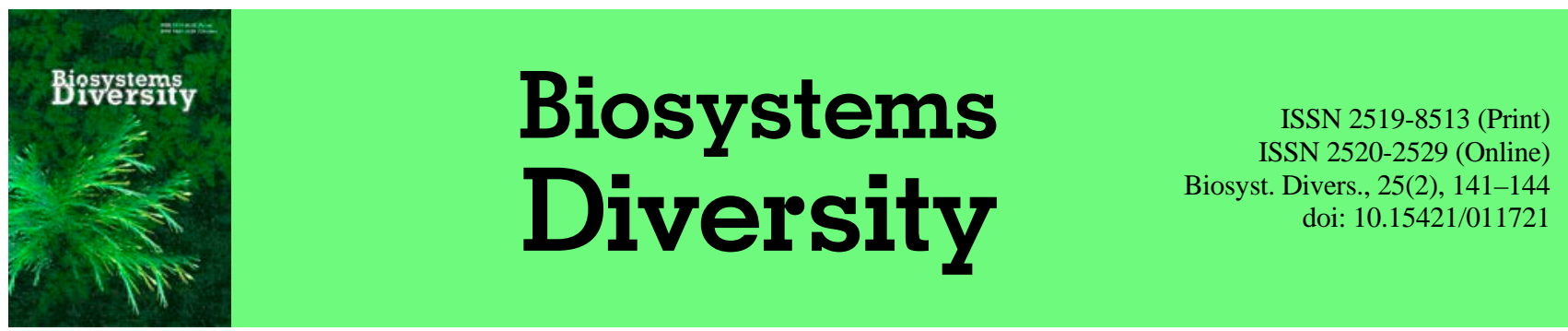

\title{
Data on spore morphology of Cerosora microphylla (Anogramma microphylla) (Pteridaceae)
}

\author{
A. V. Vaganov*, I. I. Gureyeva**, A. A. Kuznetsov**, A. I. Shmakov*, R. S. Romanets** \\ *South-Siberian Botanical Garden, Altai State University, Barnaul, Russia \\ **Tomsk State University, Tomsk, Russia
}

Article info

Received 20.04.2017

Received in revised form 11.05.2017

Accepted 14.05.2017

South-Siberian Botanical

Garden, Altai State University,

Lenin Ave., 61

Barnaul, 656049, Russia.

E-mail:vaganov_vav@mail.ru

Tomsk State University,

Lenin Ave., 36,

Tomsk, 634050, Russia.

E-mail: gureyeva@yandex.ru

\section{Introduction}

The genus Anogramma includes about five species widespread in the American tropics from Mexico to Argentina, from the Azores towards the south to the Cape Verde islands, Africa and Madagascar, southwestern and southern Europe, northern India (including Ceylon), southern Taiwan, Australia and New Zealand (Tryon, 1990).

For the flora of China, Zhang Gangmin and Tom A. Ranker report on two types: A. leptophylla (Linn.) Link and A. microphylla (Hook.) Diels (Zhang et al., 2013). The main species diversity of the representatives of Anogramma occurs in tropical and subtropical America, excluding A. leptophylla, which is found throughout the tropical and subtropical belts in all floristic realms (Gastony and Baroutsis, 1975).

According to the latest data, the genus Anogramma is part of the subfamily Pteridoideae C. Chr. ex Crabbe, the family Pteridaceae E. D. M. Kirchn. (Smith et al., 2006; Christenhusz, 2011). The results on the phylogeny of ferns obtained by independent research groups using molecular genetics show that the representatives of the genus Anogramma can be unambiguously united in the Pteridoid clade, the group of taenitioid (Zhang et al., 2005; Schuettpelz et al., 2007) and hemionitid ferns (Liu et al., 2008).

The representatives of the Pteridoid clade are referred to the ferns of the taenitioids group based on the data on the Taenitidoideae subfamily reported by Roll Trion (Tryon, 1986, 1990). However, in the research devoted to the most complete reconstruction of the molecular phylogenetic relationships of the representatives of the Pteridaceae family of Chinese-Himalayan and Afro-Madagascar origin, Harald Schneider and his colleagues referred the representatives of the genera Anogramma, Cerosora, Cosentinia and Pityrogramma to the Anogramma clade (Schneider et al., 2013).

Inside the Anogramma clade (A), with two separate subclades (A'- groups Cosentinia and Anogramma; A'”-groups Pityrogramma and A. chaerophylla), A. microphylla (indicated in the phylogenetic tree as Cerosora (A.) microphylla) stands apart from the main subclades and forms the group Cerosora together with C. (Pityrogramma) argentea var. aurea, C. (Pityrogramma) argentea var. argentea.

The representatives of the genus Cerosora exhibit a sufficiently wide disjunct distribution in Borneo, Sumatra and the Himalayas (Tryon, 1990). In 1986, Rolla Trion brought a new combination and singled out the Chinese-Himalayan representative - C.microphylla (Tryon, 1986; Schneider et al., 2013).

Despite this, in the Flora of China A. microphylla is distinguished as a representative of the predominantly neotropical genus Anogramma. In this case, the features of the external morphology of A. microphylla, including an obovate form of the final lobes of the frond and the location of the soruses along the central vein of the final frond, are not common to other representatives of the genus Anogramma.

In the relevant research conducted in 2017 that considers the phylogeny of the subfamily Pteridoideae C. Chr. ex Crabbe, the family Pteridaceae, C. microphylla takes an isolated position in the subfamily system (Zhang et al., 2017). At the same time, the group Cerosora, which includes a single representative of the genus, is closely related to the group of the representatives of Pityrogramma and Gastoniella - a new genus, which comprises three species, previously considered in Anogramma (Gastoniella Li Bing Zhang a. Liang Zhang, gen. nov., Zhang et al., 2017).

It should be noted that Rolla Trion transferred the species A. microphylla to Cerosora despite the absence of glandular hairs on the leaf surface common to all representatives of the genus Anogramma (Schneider et al., 2013). This fact testifies to the species-specific features of the external morphology of C. (A.) microphylla.

To confirm the autonomy of the Chinese-Himalayan C. (A.) microphylla, we performed scanning electron microscopy of spores of ferns collected in the Himalayas. In addition, original photographs of the A. leptophylla spore were obtained for specimens from SouthWest Asia. 
Previously, SEM was used to study the spore morphology of the representatives of Anogramma from Peru - A. leptophylla (Tryon and Lugardon, 1991) and from Argentina - A. chaerophylla (Desv.) Link and A. lorentzii (Hieron.) Diels (Giacosa et al., 2004).

\section{Material and methods}

Spores for the study were selected from the herbarium material deposited in the Herbarium of the Komarov Botanical Institute of the Russian Academy of Sciences (St. Petersburg). Three specimens collected in South-West and East Asia were investigated. The spores were fixed on a slide with an electrically conductive adhesive tape, sputtered with gold using a sputter coater Quorum Q150R S, and examined under a scanning electron microscope
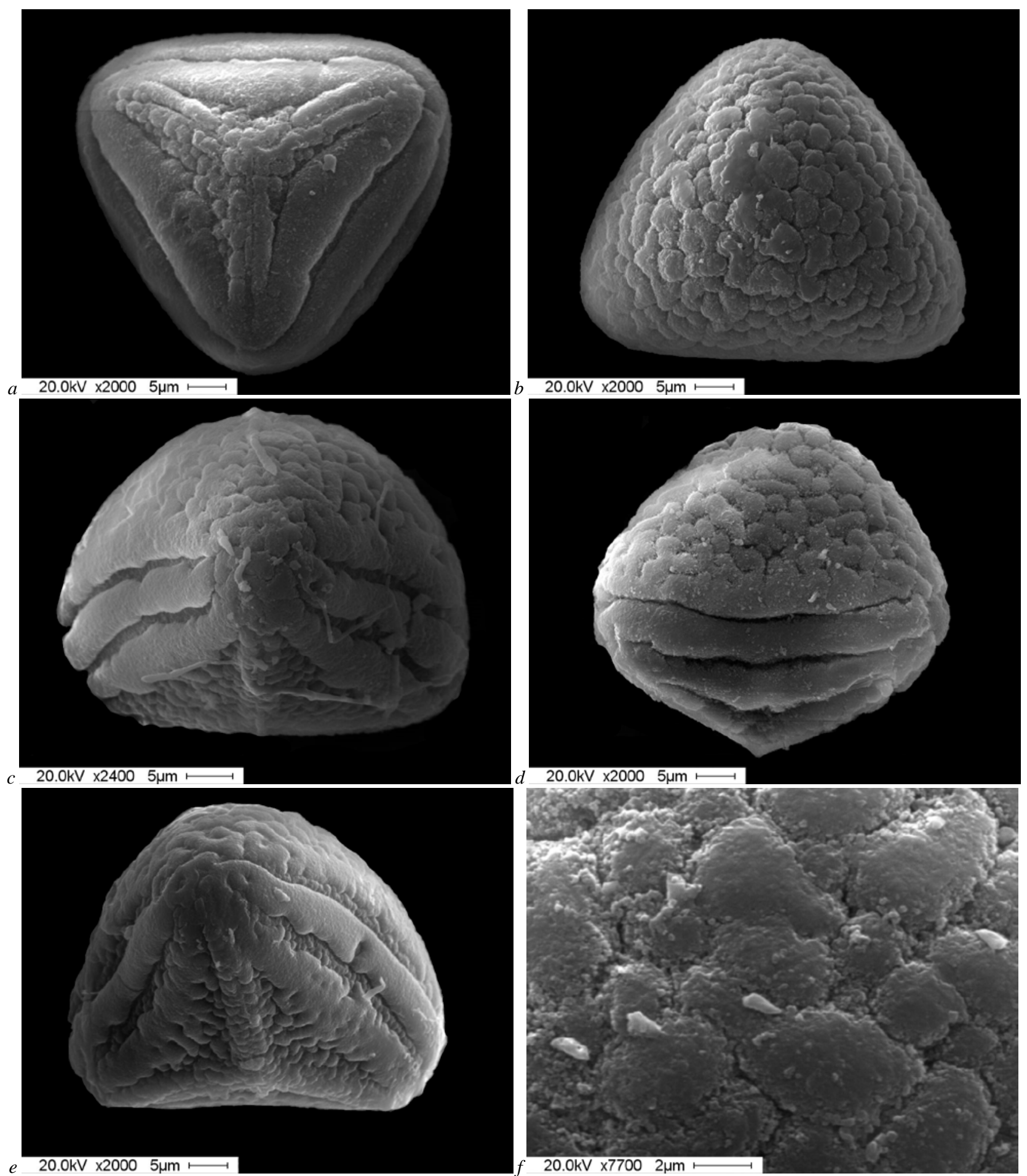

Fig. 1. SEM views of spores of Anogramma leptophylla: $a$-proximal side; $b$ - distal side; $c, d$-spore in equatorial position; $e$-spore in proximal-equatorial position; $f$ - fragment of distal surface 

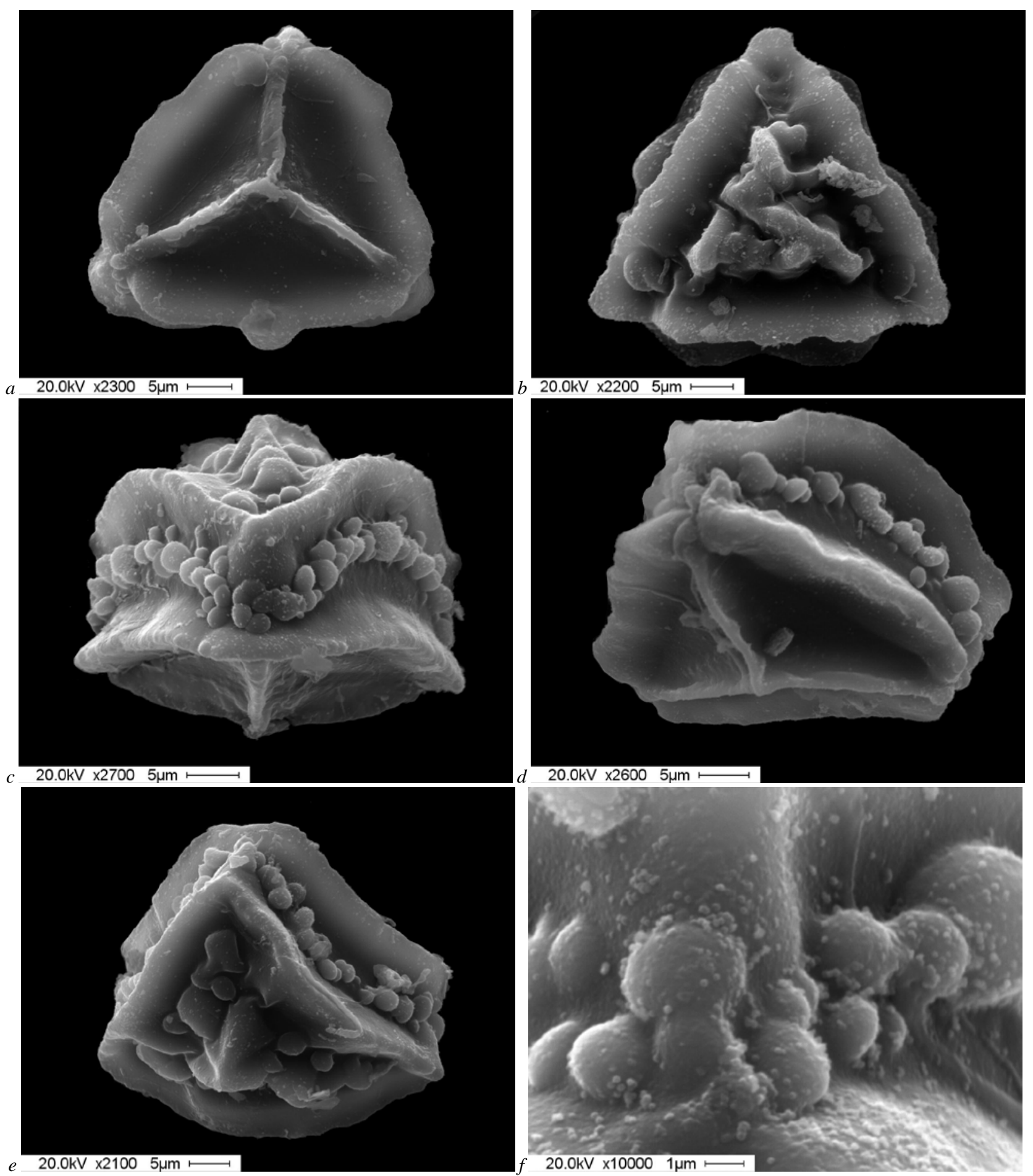

Fig. 2. SEM views of spores of Cerosora (Anogramma) microphylla: $a$ - proximal side; $b$ - distal side; $c$ - spore in equatorial position; $d$-spore in proximal-equatorial position; $e$-spore in distal-equatorial position; $f$-fragment of equatorial surface

The polar axis is (40.9) 41.7 (42.5) $\mu \mathrm{m}$. In the equatorial position, the distal side of the spore is hemispherical, the proximal side is roundish-triangular, slightly flattened. The rays of the laesura are straight, (16.0) 17.55 (19.1) $\mu \mathrm{m}$ long, (0.4) 0.6 (0.8) $\mu \mathrm{m}$ wide, merged into the roller-like bulges of the sporoderm with a width of (1.5) $1.95(2.4) \mu \mathrm{m}$. Roller-like bulges on the proximal side of the spore is are (2.9) $3.95(5.0) \mu \mathrm{m}$ wide. The tubercles of (1.0) 1.6 (2.2) $\mu \mathrm{m}$ in diameter are distributed along the entire proximal surface up to the roller-like fold outside the roller-like bulges. The width of the equatorial fold in the polar position is (5.05) $4.9(5.2) \mu \mathrm{m}$. The tubercles on the distal side are roundish, (1.4) 3.6 (5.8) $\mu \mathrm{m}$ in diameter. The exosporium surface on the distal side of the spore is granulate and distinctly expressed, the tubercles are (0.2) $0.4(0.6) \mu \mathrm{m}$ in diameter. The exosporium surface on the proximal side is rough.
Investigated specimen: Universitatis Hebraicae Hierosolymitanae Divisio Botanica Flora Terrae Israelis Exsiccata. Philistaean Plain, Mikve Israel, 16.3.1945. Lwg. A. Grizi.

A. microphylla (Hook.) Diels (C. microphylla (Hook.) R. M. Tryon) (Fig. 2). Spores in the proximal-polar position are roundish-triangular, non-lociniate, but in the distal-polar position these are triangular and lociniate. The equatorial diameter is (35.7) $38.05(40.4) \mu \mathrm{m}$. The polar axis is (28.6) $29.7(30.8) \mu \mathrm{m}$. In the equatorial position, the distal side is hemispherical, with roller-like bulges extended upward, and the proximal side is flattened. The rays of the laesura are straight, (15.0) 16.35 (17.7) $\mu \mathrm{m}$ long, (1.2) 1.5 (1.8) $\mu \mathrm{m}$ wide, rising above the sporoderm surface. The width of the roller-like fold on the distal side of the spore is 1.3 (1.2 to 1.4) $\mu \mathrm{m}$, its height is (5.3) 7.0 (8.7) $\mu \mathrm{m}$. The width of the 
roller-like fold on the proximal side of the spore is (5.7) 6.4 (7.1) $\mu \mathrm{m}$, its height is 1.1 (1.0 to 1.2) $\mu \mathrm{m}$. Spherical tubercles of (1.0) $2.4(3.8) \mu \mathrm{m}$ in diameter are arranged between the proximal and distal roller-like folds along the spore equator. On the distal side, there are sinuous folds of (2.2) 2.75 (3.3) $\mu \mathrm{m}$ in width. The exosporium surface is rough, without excrescences.

A specimen of A. microphylla (Hook.) Diels from Guizhou province was investigated in thesis by Zhang Gangmin "A systematic study on the Chinese cheilanthoid ferns and their related taxa" in 2003 (unpublished). In contrast to our SEM image, the image presented in the thesis exhibits distinctly expressed tubercles on the proximal surface of the spore between the laesura and roller-like folds.

Investigated specimen: From the Herbarium of the Royal Gardens, Kew № 1054, Himalaya. Now 2/35.

The analysis of the obtained electron micrographs and comparison of the descriptions of external morphology of spores of the representatives of the genus Anogramma from South America, C. sumatrana Holtt. from the island of Sumatra, as well as the distinctive features of the external morphology of representatives of these genera (Tryon and Lugardon, 1991; Tryon, 1986; Giacosa et al., 2004), show that the species A. microphylla can be considered separately from the genus Anogramma. The features typical of the representatives of the genus Anogramma but not of the species A. microphylla are as follows: absence of the equatorial fold, roundish-triangular spores in the proximal-polar and distal-polar positions; absence of roller-like bulges rising in the form of ridges along the contour of the distal side of the spore; highly risen roller-like folds on both the proximal and distal sides of the spore.

The analysis of the clades of the phylogenetic trees obtained for the representatives of the family Pteridaceae (Schneider et al., 2013; Zhang et al., 2017) and the data obtained in the study of morphology of fern spores of this group have shown that the species A. microphylla (Hook.) is Sino-Himalayan C. microphylla (Hook.) R. M. Tryon. In contrast to the external morphology of spores of $C$. sumatrana (Tryon and Lugardon, 1991), the feature revealed for C. microphylla - spherical tubercles between the proximal and distal roller-like folds located along the spore equator - indicates its high species-specificity.

\section{References}

Christenhusz, M. J. M., Zhang, X.-C., \& Schneider, H. (2011). A linear sequence of extant families and genera of lycophytes and ferns. Phytotaxa, 19, 7-54.
Gastony, G. J., \& Baroutsis, J. G. (1975). Chromosome numbers in the genus Anogramma. American Fern Journal, 65(3), 71-75.

Giacosa, J. R., Morbelli, M., \& Giudice, G. (2004). Spore wall ultrastructure in Anogramma species (Pteridaceae) from Argentina. Grana, 43, 231-237.

Liu, H.-M., Wang, L., Zhang, X.-Ch., \& Zeng, H. (2008). Advances in the studies of lycophytes and monilophytes with reference to systematic arrangement of families distributed in China. Journal of Systematics and Evolution, 46(6), 808-829.

Schneider, H., He, L., Hennequin, S., \& Zhang, X.-C. (2013). Towards a natural classification of Pteridaceae: Inferring the relationships of enigmatic pteridoid fern species occurring in the Sino-Himalaya and Afro-Madagascar. Phytotaxa, 77(4), 49-60.

Schuettpelz, E., \& Pryer, K. M. (2008). Fern phylogeny. Biology and evolution of ferns and lycophytes, 395-416.

Schuettpelz, E., Schneider, H., Huiet, L., Windham, M. D., \& Pryer, K. M. (2007). A molecular phylogeny of the fern family Pteridaceae: Assessing overall relationships and the affinities of previously unsampled genera. Molecular Phylogenetics and Evolution, 44, 1172-1185.

Smith, A. R., Kathleen, M. P., Schuettpelz, E., Korall, P., Schneider, H., \& Wolf, P. G. (2006). A classification for extant ferns. Taxon, 55, 705-731.

Tryon, R. (1986). Some new names and combination in Pteridaceae. American Fern Journal, 76(4), 1-185.

Tryon, R. M. (1990). Pteridaceae. In: Kramer, K. U., \& Green, P. S. (vol. eds.). Pteridophytes and Gymnosperms. In: Kubitzki K. (ed.) The families and genera of vascular plants. Springer, Berlin, 230-256.

Tryon, R. M. (1986). Some new names and combinations in Pteridaceae. American Fern Journal, 76, 184-186.

Tryon, A. F., \& Lugardon, B. (1991). The spores of pteridophytes: Surface, wall structure, and diversity based on electron microscopy studies. Springer, Berlin.

Zhang, G., Zhang, X., \& Chen, Z. (2005). Phylogeny of cryptogrammoid ferns and related taxa based on rbcL sequences. Nordic Journal of Botany, 23, 485-493.

Zhang, L., Zhou, X.-M., Thi Lu, N., \& Zhang, L.-B. (2017). Phylogeny of the fern subfamily Pteridoideae (Pteridaceae; Pteridophyta), with the description of a new genus: Gastoniella. Molecular Phylogenetics and Evolution, 109, 59-72.

Zhang, G. M., Liao, W. B., Ding, M. Y., Lin, Y. X., Wu, Z. H., Zhang, X. C., Dong, S. Y., Prado, J., Gilbert, M. G., Yatskievych, G., Ranker, T. A., Hooper, E. A., Alverson, E. R., Metzgar, J. S., Funston, A. M., Masuyama, S., \& Kato, M. (2013). Pteridaceae. In: Wu, Z. Y., Raven, P. H., \& Hong, D. Y. (eds.). Flora of China, 2-3 (Pteridophytes). Science Press, Beijing; Missouri Botanical Garden Press, St. Louis, 169-256. 